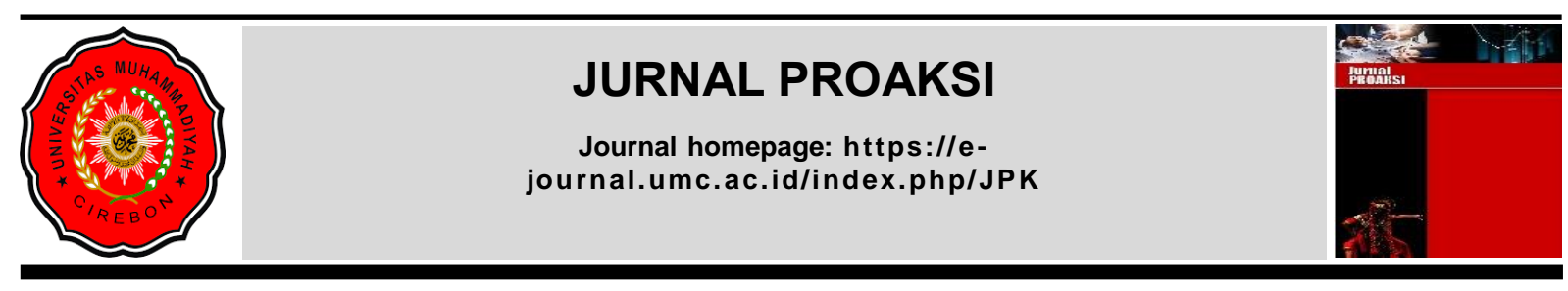

\title{
FAKTOR-FAKTOR YANG MEMENGARUHI NILAI PERUSAHAAN DENGAN CSR SEBAGAI VARIABEL MODERASI
}

\author{
Dewi Tamara Rahmadhani ${ }^{1}$, \\ Saiful Anwar ${ }^{*}$ \\ ${ }^{1}$ Universitas Pembangunan Nasional Veteran Jawa Timur \\ Email: dewitamara8@gmail.com \\ ${ }^{2}$ Universitas Pembangunan Nasional Veteran Jawa Timur \\ *Corresponden Author Email : saifulupn@ gmail.com
}

Diterima : 25 Agustus $2021 \quad$ Direvisi : 26 September $2021 \quad$ Dipublikasikan : 17 Oktober 2021

\begin{abstract}
One tool for measuring profits is the value of the company, because it can help executives and managers to succeed in managing the company's finances. Shareholders certainly want a high company value reflected in the high value of shares as well. Therefore, it is believed to be able to provide a high level of well-being to shareholders. The purpose of the research is to test and prove that CSR strengthens the factors of firm value in company basic industrial and chemical manufacturing listed on Indonesia Stock Exchange in 2015-2019. This research type uses a quantitative research approach. Sample determining method using purposive sampling on 71 manufacturing companies that publish annual report in 5-year study period. Technique data analysis using PLS (Partial Least Square) by Warp PLS software version 7.0. From hypothesis testing results, it's concluded that GCG has no effect on firm value, financial performance has a significant positive effect on firm value, firm size has a significant negative effect on firm value, and CSR as variabel moderator showed unable to moderate the impact of GCG, financial performace, and firm size againt firm value.
\end{abstract}

Keywords: GCG, ROA, Size, CSR, Tobins' $Q$

\section{PENDAHULUAN}

Perusahaan pada umumnya adalah bentuk organisasi yang memiliki tujuan khusus untuk memuaskan kepentingan para pemangku kepentingannya atau untuk menumbuhkan harta kekayaan principal dengan meningkatkan nilai perusahaan. peningkatan nilai suatu perusahaan terlihat dari kemampuannya mengelola dan mencapai tujuan laba. Nilai perusahaan menggambarkan keadaan atau kondisi dari perusahaan tersebut. Nilai suatu perusahaan dinyatakan sebagai nilai yang ditentukan oleh harga saham yang diperdagangkan di pasar modal (Harmono, 2011). Semakin tinggi harga saham, semakin besar kekayaan pemegang saham. Salah satu indicator untuk menilai potensi nilai perusahaan tersebut dalam menghasilkan keuntungan. Keuntungan perusahaan meningkat secara signifikan menandakan bahwa perusahaan berjalan dengan baik dalam pengelolaan bisnis.

Pertumbuhan nilai perusahaan manufaktur berkaitan langsung dengan kebiasaan konsumsi masyarakat sehari-hari. Namun, dalam beberapa tahun terakhir, tingkat pertumbuhan nilai industri manufaktur berfluktuasi atau naik-turun. Tabel 1 dapat dilihat merupakan data nilai perusahaan dari beberapa perusahaan dalam kurun waktu 5 tahun.

Tabel 1. Data Nilai Perusahaan

\begin{tabular}{ccccccc}
\hline \multirow{2}{*}{ NO } & \multirow{2}{*}{ Nama Perusahaan } & \multicolumn{5}{c}{ Nilai Perusahaan (Tobins'Q) } \\
\cline { 3 - 7 } & & $\mathbf{2 0 1 5}$ & $\mathbf{2 0 1 6}$ & $\mathbf{2 0 1 7}$ & $\mathbf{2 0 1 8}$ & $\mathbf{2 0 1 9}$ \\
\hline 1 & Asiaplast Industries Tbk & 0,60 & 0,74 & 0,68 & 0,82 & 1,07 \\
\hline 2 & Berlina Tbk & 0,59 & 1,02 & 1,18 & 1,02 & 1,04 \\
\hline
\end{tabular}




\begin{tabular}{ccccccc}
\hline 3 & Trias Sentosa Tbk & 0,68 & 0,67 & 0,72 & 0,74 & 0,75 \\
\hline 4 & Yanaprima Hastapersada Tbk & 2,37 & 2,50 & 2,71 & 2,22 & 1,88 \\
\hline 5 & Kedawung Setia Industrial Tbk & 0,74 & 0,76 & 0,80 & 0,89 & 0,91 \\
\hline 6 & Aneka Gas Industri Tbk & 0,62 & 0,97 & 0,75 & 0,84 & 0,83 \\
\hline 7 & Duta Pertiwi Nusantara Tbk & 0,59 & 0,56 & 0,51 & 0,46 & 0,38 \\
\hline 8 & Indo Acidama Tbk & 0,93 & 0,86 & 0,82 & 0,86 & 0,86 \\
\hline 9 & Saranacentral Bajatama Tbk & 0,95 & 1,40 & 1,12 & 1,14 & 1,04 \\
\hline 10 & Gunawan Dianjaya Steel Tbk & 2,14 & 1,08 & 0,87 & 0,98 & 0,80 \\
\hline
\end{tabular}

Sumber : Data diolah Penulis, 2021

Perubahan pertumbuhan nilai perusahaan yang tidak menentu ini merupakan fenomena yang menarik untuk diteliti. Hal inilah yang menunjukkan bahwa adanya faktor-fator tertentu yang menyebabkan peningkatan atau penurunan nilai perusahan yang terjadi di perusahaan manufaktur. Good Corporate Governance adalah suatu metode yang digunakan untuk mengurangi konflik agensi di suatu perusahaan yang bertujuan untuk menselaraskan kepentingan manajemen dan shareholder. Menerapkan tata kelola perusahaan baik adalah salah satu langkah kunci untuk meningkatkan nilai perusahaan. Metode ini terdiri dari kepemilikan manajemen (manajerial). Dengan diterapkannya fungsi kepemilikan manajerial yang efektif akan meningkatkan pengawasan terhadap perusahaan yang lebih baik dalam mengurangi adanya biaya keagenan. Sekaligus, sebagai pemilik perusahaan, manajer secara langsung merasakan benefit dan kerugian dari keputusan yang ia ambil. Semakin tinggi rasio kepemilikan manajemen, semakin selaras kepentingan manajemen dan pemegang saham, serta nilai da kinerja perusahaan diharapkan akan meningkat.

Kinerja keuangan merupakan faktor yang diperhitungkan dalam hubungannya dengan nilai perusahaan. Tingginya nilai perusahaan menunjukkan bahwa kualitas kinerja atau laba perusahaan baik. Kualitas laba atau kinerja keuangan suatu perusahaan adalah faktor yang dipertimbangkan oleh calon investor Ketika memutuskan untuk berinvestasi pada suatu saham. Semakin baik kaualitas laba perusahaan, maka semakin diperhitungkan pula persektif masa depan perusahaan tersebut. Dengan kata lain, nilai perusahaan juga dievaluasi untuk ditingkatkan dari sudut pandang investor. Salah satu indicator kinerja perusahaan yang paling umum digunakan sebagai dasar pengambilan keputusan adalah profitabilitas. Profitabilitas (margin laba) adalah kemampuan perusahaan untuk mendapatkan laba atau keuntungan dari segi penjualan, total asset, dan ekuitas (Sartono, 2010). Profitabilitas suatu perusahaan menunjukkan ukuran efektivitas pengelolaan manajemen perusahaan dan kemampuan perusahaan untuk mendapatkan laba (Kasmir, 2014). Ketika margin profit mengalami kenaikan, hal ini mencerminkan kinerja di dalam perusahaan tersebut baik dan sebagai sinyal untuk para investor berinvestasi dalam perusahaan itu, dan nilai perusahaan mengalami peningkatan.

Ukuran (besar kecil) perusahaan dianggap dapat memengaruhi nilainya suatu perusahaan, dimana besarnya skala perusahaan, akan memudahkan untuk menghasilkan pendanaan secara internal dan eksternal. Ukuran perusahaan ini menggambarkan total asset dari sebuah perusahaan. perusahaan itu sendiri terbagi dalam dua ketegori yaitu perusahaan berukuran kecil dan berukuran besar. Perusahaan yang berukuran besar cenderung menarik investor karena memengaruhi nilai perusahaan kedepannya, dan disimpulkan bahwa ukuran perusahaan berpengaruh langsung terhadap nilai perusahaan (Rudangga \& Sudiarta, 2016). Selain itu, peneliti menambahkan pengungkapan tanggung jawab sosial (CSR) sebagai variabel moderasi. CSR ini dipilih karena memberikan tanggung jawab besar atas penggunaan sumber daya alam, dimana dalam pemanfaatannya berakibat langsung terhadap lingkungan dan Negara Indonesia menjadi salah satu negara di dunia yang memiliki sumber daya alam (SDM) sangat banyak, termasuk bahan baku industri. Hasrat untuk mencari profit sebanyak-banyaknya menyebabkan perusahaan melakukan kegaiatan yang acuh terhadap kondisi lingkungan. Perusahaan lebih sering melangsungkan aktivitas ekonomi dan pembangunannya dengan membiarkan imbas sosial dan lingkungan yang ditimbulkan seperti masalah sosial masyarakat, polusi, dan pemanasan global oleh (Haryono dan Iskandar, 2015).

Beberapa peneltian terdahulu dengan pengaruh GCG (kepemilikan manajerial), kinerja keuangan (ROA), dan ukuran perusahaan dalam memengaruhi nilai perusahaan diukur dengan Tobin's Q, diantaranya dilakukan oleh Berliani \& Riduwan (2017) memperlihatkan GCG mempunyai pengaruh positif signifikan terhadap nilai perusahaan. Kemudian ada hasil berbeda oleh Rahma et al., (2014) dan 
Budianto \& Payamta (2014) yang memperlihatkan GCG mempunyai pengaruh negatif signifikan terhadap nilai perusahaan. Penelitian berkaitan dengan hubungan kinerja keuangan yang diproksi melalui ROA (return on asset) dengan nilai perusahaan dilakukan oleh Harningsih et al., (2019) serta Chumaidah \& Priyadi, (2018) menyatakan ROA pengaruhnya positif signifikan pada nilai perusahaan. Lalu penelitian oleh Triagustina et al., (2014) menyatakan sebaliknya bahwa ROA pengaruhnya negatif signifikan pada nilai perusahaan. Lalu penelitian oleh Rudangga \& Sudiarta (2016) serta Rahma et al., (2014) mengatakan ukuran perusahaan mempunyai pengaruh positif signifikan dan sebaliknya penelitian oleh Onasis dan Robin (2016) menunjukkan ukuran perusahaan membuktikan ada pengaruh negatif signifikan terhadap nilai perusahaan.

Hubungan CSR dalam memoderasi GCG (kepemilikan manajerial) ditunjukkan melalui hasil penelitian sebelumnya oleh Prastuti \& Budiarsih (2015) mengatakan bahwa CSR tidak memoderasi, namun penelitian Widianingsih (2018) memoderasi terhadap nilai perusahaan. Disisi lain, penelitian Chumaidah \& Priyadi, (2018); Susilaningrum (2016); Lestari \& Rahmayanti (2019); Dewi \& Suputra2 (2019); dan Pradita \& Suryono (2019) CSR mampu memoderasi kinerja keuangan (ROA). Sebaliknya penelitian Harningsih et al., (2019); Wahyuni \& Hidayati (2018); dan Funawati \& Kurnia (2017) tidak memoderasi pengaruh ROA terhdap nilai perusahaan. Selanjutnya, penelitian lain oleh Pradita \& Suryono (2019)menunjukkan hasil bahwa CSR memoderasi ukuran perusahaan terhadap nilai perusahaan, tetapi bertentangan dengan penelitian Chumaidah \& Priyadi, (2018); yang tidak memoderasi ukuran perusahaan pada nilai perusahaan.

Berdasarkan uraian di atas, adanya ketidakkonsistenan hasil riset/penelitian sebelumnya, maka penelitian ini bertujuan untuk meneliti lebih lanjut sehingga dapat menjawab permasalahan yang telah dirumuskan dengan bertujuan untuk membuktikan secara empiris pengaruh GCG yang diproksi kepemilikan manajerial, kinerja keuangan (ROA), ukuran perusahaan (size), serta untuk membuktikan pengaruh KM, ROA, ukuran perusahaan terhadap nilai perusahaan dengan pengungkapan corporate social responsibility sebagai variabel pemoderasi.

\section{KAJIAN PUSTAKA DAN PENGEMBANGAN HIPOTESIS Teori Sinyal}

Teori ini menggambarkan bagaimana sebuah perusahaan memiliki dorongan motivasi untuk membagikan mengenai informasi laporan keuangan maupun nonkeuangannya secara terbuka kepada pihak yang berkepentingan. Keadaan yang mendorong perusahaan ini terjadi diakibatkan oleh asimetri informasi pihak internal dan eksternal dimana menambah untuk mengetahui informasi tentang perusahaan dan peluang di masa depannya dari pihak golongan luar (investor dan kreditor) (Purwantoro, 2020). Hal inilah yang menyebabkan pihak investor dan kreditor memberikan harga yang rendah kepada perusahaan. Oleh karena itu, untuk mengurangi asimetri informasi ini akan sangat bagus jika perusahaan dapat memberi sinyal kepada orang luar.

\section{Teori Keagenan (Agency Theory)}

Teori agen adalah teori dasar yang biasa dipakai untuk menguasai isu-isu mengenai Good Corporate Governance dimana teori ini berkaitan dengan hubungan dengan pemilik dan agen dari perspektif manajemen perusahaan. Ada kesenjangan antara pemegang saham dan manajemen cenderung menimbulkan masalah keagenan dimana hal ini kepentingan antara keduanya sering terjadi dikarenakan manajemen tidak selalu berperan sesuai dengan kehendak pemegang saham dan biaya keagenan yang nantinya akan dikeluarkan. Konflik principal-agent, dapat dikurangi dengan mekanisme pengawasan tata kelola perusahaan yang baik, termasuk komite audite, komisaris independent, kepemilikan institusional, dan kepemilikan manajer.

\section{Teori Legitimasi}

Menurut Sayekti dan Wondablo (2007) dan Benne \& Moningka (2020), teori letigimasi merupakan komitmen antara perusahaan dengan masyarakat guna dalam pelaksanaan kegiatan operasionalnya berdasarkan nilai-nilai justice, yang bisa dikatakan dari sistem nilai perusahaan dapat searah dengan masyarakat sehingga sangat dianjurkan sebuah perusahaan dalam kegiatan operasionalnya dan kinerjanya dapat disambut oleh kalangan masyarakat sekitar kegiatan bisnisnya. Oleh karena itu, dengan diterimanya oleh masyarakat, meningkatnya pula nilai perusahaan. 


\section{Nilai Perusahaan}

Nilai perusahaan (firm value) digambarkan bagaimana kondisi baik atau buruknya pengelolaan kekayaan manajemen, hal ini terlihat dari kinerja keuangannya pada suatu perusahaan dalam penggunaan asset serta modalnya untuk memperoleh keuntungan yang optimal. Nilai perusahaan dianggap sangat berarti karena mampu memengaruhi kesan terhadap perusahaan. Menurut Sujoko \& Subyantoro (2007), nilai perusahaan adalah pemahaman investor bahwa kesuksesan sebuah perusahaan kerap diakaitkan melalui harga saham. Peningkataan ini akan mengarah pada kesejahteraan dan kemakmuran pemegang saham. Ketika nilai perusahaan tinggi, struktur keuangan perusahaan baik dan manajer memenuhi tugas dan tanggung jawabnya dalam menjalankan perusahaan. Nilai suatu perusahaan tercermin dari harga saham, semakin tinggi nilai perusahan begitu juga dengan kekayaan pemegang saham. Tingginya nilai suatu perusahaan menjadi alasan para investor tertarik untuk menanamkan modalnya. Oleh sebab itu, kenaikan nilai harga saham dapat membawa nilai positif dari investor terhadap manajemen. Dengan cara ini, manajemen termotivasi untuk terus memberikan nilai tambah bagi perusahaan.

\section{Corporate Social Responsibility}

CSR (tanggung jawab sosial) diartikan sebagai teori dan perilaku tanggung jawab kepada lingkungan dan masyarakat sekitar dalam kegiatan operasional perusahaan (Pradita \& Suryono, 2019). Dengan menerapkan CSR dapat menaikkan nilai perusahaan dan memberikan benefit untuk para pemangku kepentingan dan pemegang saham. Oleh karena itu, jika sebuah perusahaan ingin menaikkan nilainya, faktor yang perlu dipertimbangkan adalah masalah sosial dan lingkungan dalam proses pengambilan keputusan (Prastuti \& Budiarsih, 2015) . Seperti yang dikatakan oleh John Elkington, ada tiga aspek implementasi CSR atau biasa disebut 3P (profit, people, planet) yang dijelaskan bahwa suatu perusahaan jika ingin tetap bertahan maka tidak berpusat pada keuntungan saja, tetapi harus dapat memberikan partisipasi kepada masyarakat serta ikut dalam memelihara dan menjaga lingkungan (Benne \& Moningka, 2020). Salah satu kriteria CSR dalam penelitian ini diukur dengan pedoman Global Reporting Initiative (G4).

\section{Good Corporate Governance}

Tata kelola perusahaan baik (GCG) adalah bagaimana investor berpikir bahwa manajer akan menguntungkan mereka, tidak mencuri, menggunakan atau berivestasi dalam pekerjaan yang merugikan terkait dana/modal investor dan yang mengontrol hubungan investor-manajer. Salah satunya, tata kelola perusahaan yang baik di penelitian ini menggunakan structural kepemilikan manajerial. Insider ownership (kepemilikan manajer) adalah rasio pemegang saham di pihak manajemen dengan total saham beredar pada tahun tertentu. Manajemen ini termasuk dewan komisaris dan dewan direktur perusahaan. Kepemilikan manajemen dapat diukur dengan rasio yang dimiliki dewan manajer, direksi, dan komisaris yang didapat dari laporan keuangan (Widianingsih, 2018).

\section{Kinerja Keuangan}

Kinerja keuangan adalah ukuran yang dipergunakan oleh perusahaan guna memperkirakan seberapa besar perusahaan untuk menghasilkan keuntungan dan kemampuan untuk memenuhi kewajiban pemangku kepentingan kepada kreditur yang menjadi bagian penting dari perusahaan untuk meningkatkan nilai perusahaan dengan memberikan prospek masa depan yang baik (Purwantoro, 2020). Dengan kinerja keuangan, perusahaan dapat dengan mudah untuk mengetahui kondisi keuangannya di setiap periode tertentu baik terkait segi pendanaan maupun penyalurannya. Di penelitian ini menggunakan Return on Asset untuk mengukur kinerja keuangan. ROA digunakan untuk melihat kapabilitas perusahaan dalam menghasilkan keuntungan di masa datang dengan gambaran dari masa lalu (Meze \& Tohar, 2020). ROA disebut juga sebagai pengembalian asset yang menandakan bahwa margin keuntungan diperoleh atas rata-rata total asset dan sumber daya perusahaan. Dengan begitu, perusahaan yang menguntungkan akan menarik perhatian investor untuk menempatkan modal mereka dengan harapan pengembaian yang tinggi.

\section{Ukuran Perusahaan}

Ukuran perusahaan adalah rasio untuk mengklasifikasikan kecil besarnya ukuran perusahaan dengan berbagai cara, seperti total asset, total penjualan, rata-rata total asset, dan rata-rata total penjualan (Sujianto, 2001). Ukuran perusahaan juga dapat dipahami sebagai perbandingan kecil besarnya ukuran 
suatu perusahaan atau organisasi. Oleh karena itu, ukuran suatu perusahaan dapat dianggap mampu menentukan atau mengukur kecil besarnya nilai perusaahaan.

\section{Pengaruh Good Corporate Governance Terhadap Nilai Perusahaan}

Setiap perusahaan tidak terlepas dari berbagai masalah, salah satunya adalah masalah keagenan yang terjadi di dalam internal perusahaan. Berdasarkan teori keagenan, konflik antara principal dengan agent akan terjadi jika persentase kepemilikan manajerial kecil. Hal ini dapat menjadi penyebab tindakan manajer yang cenderung menguntungkan pribadinya sendiri tanpa memperdulikan keinginan dari principal sehingga justru akan menambah biaya bagi perusahaan. Masalah keagenan ini dapat diminimalkan dengan menerapkan struktur kepemilikan saham manajerial dalam perusahaan. Dengan begitu, manajer akan termotivasi dalam meningkatkan kinerjanya untuk mengelola perusahaan sehingga nilai perusahaan dapat meningkat. Sesuai dengan penelitian Berliani \& Riduwan (2017) yang menunjukkan bahawa kepemilikan manajerial berpengaruh positif signifikan terhadap nilai perusahaan. $\mathrm{H}_{1}$ : GCG berpengaruh terhadap nilai perusahaan

\section{Pengaruh Kinerja Keuangan Terhadap Nilai Perusahaan}

Return on Assets (ROA) adalah salah satu rasio profitabilitas yang paling umum digunakan dalam penelitian sebagai variabel kinerja keuangan. Rasio ini digunakan untuk mengukur perusahaan yang menghasilkan keuntungan dengan menggunakan total aset mereka (Pradita \& Suryono, 2019). Semakin tinggi ROA, semakin efisien dan efektif perusahaan menggunakan harta/asset keseluruhannya (Berliani \& Riduwan, 2017). Hasil penelitian Dewi \& Suputra2 (2019), Purwantoro (2020) menemukan bahwa ROA berpengaruh positif signifikan terhadap nilai perusahaan. Dalam hal ini, semakin tinggi ROA perusahaan maka semakin baik kinerja keuangannya dalam mengelola asset yang dimiliki.

$\mathrm{H}_{2}$ : ROA berpengaruh terhadap nilai perusahaan

\section{Pengaruh Ukuran Perusahaan Terhadap Nilai Perusahaan}

Ukuran perusahaan merupakan variabel yang diduga memengaruhi nilai suatu perusahaan. Dalam teori sinyal, total asset yang besar di perusahaan merupakan sinyal baik bagi investor bahwa perusahaan akan memiliki peluang yang baik untuk masa datang. Dengan begitu, akan lebih mudah memperoleh dana dari para investor dan mudah mengakses ke pasar modal. Pernyataan tersebut didukung oleh penelitian Rahma et al. (2014) yang mengatakan bahwa ukuran perusahaan berpengaruh positif signifikan terhadap nilai perusahaan. Berdasarkan uraian tersebut, maka dirumuskan hipotesis sebagai berikut:

$\mathrm{H}_{3}$ : Ukuran perusahaan berpengaruh terhadap nilai perusahaan

\section{Corporate Social Responsibility Sebagai Pemoderasi Pengaruh Good Corporate Governance Terhadap Nilai Perusahaan}

Dalam penelitian ini, peneliti juga menambahkan CSR yang menjadi variabel pemoderasi antara GCG dan nilai perusahaan. GCG adalah menyangkut tanggung jawab perusahaan kepada pihak lain yang berkepentingan dengan kegiatan ekonomi dan dampaknya, dan CSR merupakan wujud tindakan dari kepedulian dan tanggung jawab sosial dalam mengatasi kerentanan dan kerusakan lingkungan yang disebabkan oleh kegiatan bisnis dari perusahaan. Dengan melalui program-program CSR yang dilakukan oleh pihak perusahaan inilah yang dapat memberikan image baik dan meningkatkan nilai perusahaan yang akan menguntungkan perusahaan. Oleh karena itu, apabila suatu perusahaan ingin nilai perusahaan mengalami peningkatan maka yang harus dilakukan adalah mempertimbangkan berbagai masalah sosial dan lingkungan dalam pengambilan keputusan. Sesuai dengan penelitian Widianingsih (2018) yang menunjukkan bahwa besar kecilnya praktik CSR dapat memoderasi peningkatan nilai perusahaan. Sebaliknya, dengan penelitian Prastuti \& Budiarsih (2015) tidak dapat memoderasi hubungan antara GCG terhadap nilai perusahaan yang diproksi kepemilikan manajerial. Berdasarkan uraian tersebut, maka dirumuskan hipotesis sebagai berikut:

$\mathbf{H}_{4}$ : CSR dapat memoderasi pengaruh GCG terhadap nilai perusahaan

\section{Corporate Social Responsibility Sebagai Pemoderasi Pengaruh Kinerja Keuangan Terhadap Nilai Perusahaan}

Pada saat perusahaan tingkat profitabilitasnya tinggi dengan disertai pengungkapan CSR yang tinggi juga, maka persepsi para investor juga akan semakin meningkat terhadap perusahaan tersebut (Wahyuni \& Hidayati, 2018). Dengan begitu, nantinya calon investor akan lebih tertarik untuk 
menanamkan modalnya dengan perusahaan yang memiliki nilai profitabilitas tinggi dan mengekspos infomasi CSR dengan baik yang berpengaruh akan meningkatkan nilai perusahaan. Penelitian sebelumnya tentang pengaruh kinerja keuangan terhadap nilai perusahaan dengan CSR menjadi variabel moderasi. Banyak atau hampir semua penelitian yang menggunakan proksi ROA membuktikan bahwa ROA memengaruhi pengungkapan CSR dan tidak berpengaruh terhadap nilai perusahaan. Hal ini sesuai dengan pendapat yang diteliti oleh Chumaidah \& Priyadi (2018), Susilaningrum (2016), Lestari \& Rahmayanti (2019), Dewi \& Suputra (2019) dan Pradita \& Suryono (2019) yang menyatakan bahwa CSR dapat memoderasi pengaruh kinerja keuangan (ROA) terhadap nilai perusahaan. Ini berarti bahwa dengan meningkatnya tanggung jawab sosial perusahaan, demikian pula dampaknya memperkuat pengaruh kinerja keuangan pada perusahaan. Berdasarkan uraian tersebut, maka dirumuskan hipotesis sebagai berikut:

$\mathrm{H}_{5}$ : CSR dapat memoderasi pengaruh ROA terhadap nilai perusahaan

\section{Corporate Social Responsibility Sebagai Pemoderasi Pengaruh Ukuran Perusahaan Terhadap Nilai Perusahaan}

Seiring dengan pertumbuhan ukuran perusahaan, peran CSR dinilai sangat penting, semikian pula dengan kewajiban untuk melaksanakan CSR perusahaan. Oleh karena itu, perusahaan dapat mengekspos program sosialnya yang bertujuan untuk menciptakan citra dan reputasi perusahaan yang baik bagi, berkat partisipasi dan kontribusi mereka terhadap lingkungan dimana perusahaan berada serta dapat memperoleh legitimasi sosial dari masyarakat akibat kerusakan yang timbul dari kegiatan bisnis perusahaan. Di sisi lain, perusahaan juga akan mengalami peningkatan keuntungan dibandingkan dari sebelum penerapan CSR. Penelitian yang diteliti oleh Pradita \& Suryono (2019) menunjukkan bahwa corporate social responsibility dapat memoderasi pengaruh ukuran perusahaan terhadap nilai perusahaan. Bertentangan dengan penelitian Chumaidah \& Priyadi (2018) yang mengatakan bahwa corporate social responsibility tidak mampu memperkuat pengaruh variabel ukuran perusahaan ini terhadap nilai perusahaan. Berdasarkan uraian tersebut, maka dirumuskan hipotesis sebagai berikut:

$\mathrm{H}_{6}$ : CSR dapat memoderasi pengaruh ukuran perusahaan terhadap nilai perusahaan

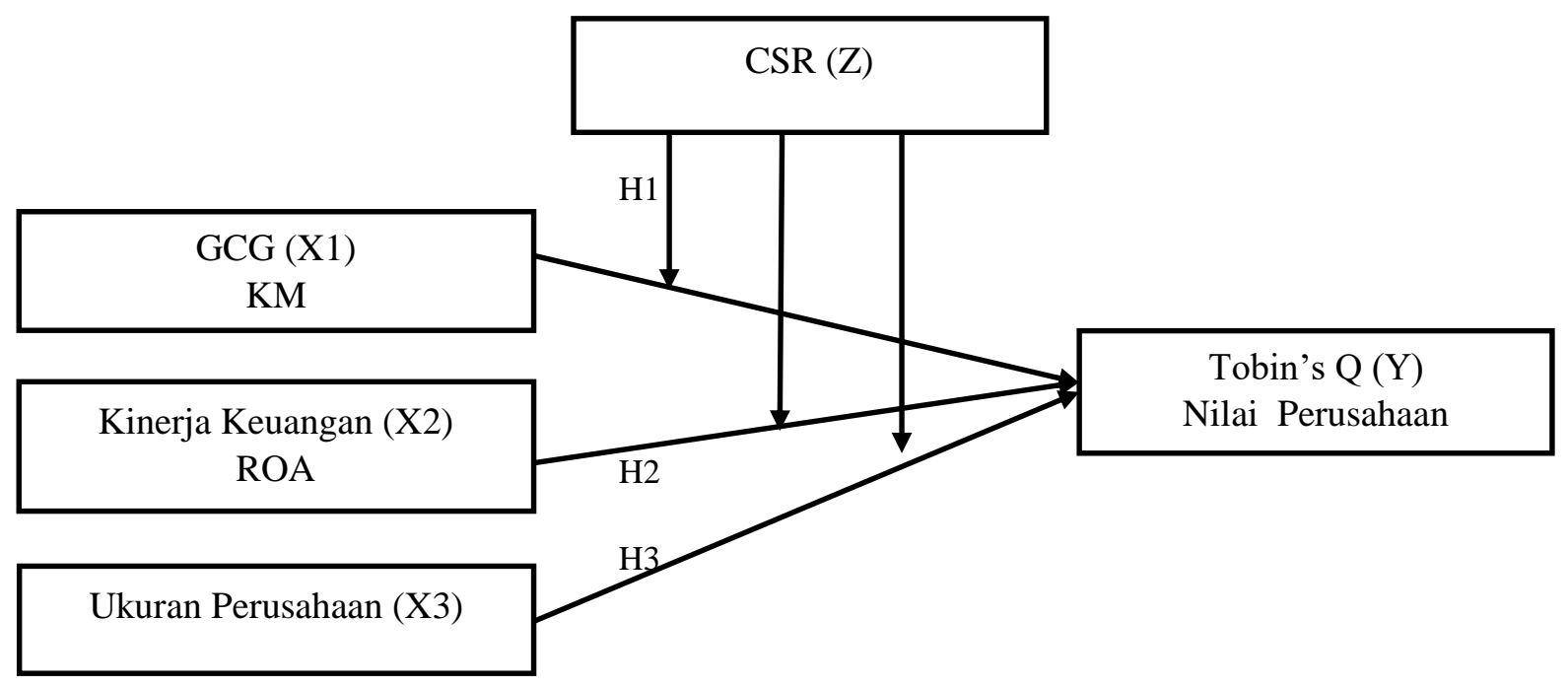

Gambar 1. Kerangka Pemikiran

\section{METODE PENELITIAN \\ Jenis Penelitian}

Jenis penelitian ini memakai pendekatan kuantitatif karena datanya penelitian ini mengacu pada perhitungan numerik dan dianalisis menggunakan statistik untuk tujuan pengujian dan pembuktian hipotesis dalam.

\section{Populasi dan Sampel}

Populasi penelitian ini yaitu laporan tahunan dan keuangan dari sektor perusahaan manufacture di industri dasar dan kimia yang tercatat di BEI periode tahun 2015 hingga 2019.Teknik pengumpulan sampel ini menggunakan teknik purposive sampling, yaitu teknik penentuan sampel yang mempertimbangkan tertentu (Sugiyono, 2016), dengan diperoleh 21 perusahaan selama 5 tahun. 
Penggunaan teknik ini dipilih karena dianggap mampu mewakili karakteristik populasi secara keseluruhan. Berikut kriteria-kriteria yang digunakan Peneliti dalam menentukan sampel:

Tabel 2. Kriteria Sampel

\begin{tabular}{lc}
\hline \multicolumn{1}{c}{ Keterangan } & Jumlah \\
\hline $\begin{array}{l}\text { Perusahaan (firm) industry manufacture dasar dan kimia yang } \\
\text { terdaftar di BEI selama } 5 \text { tahun yaitu 2015-2019 }\end{array}$ & 71 \\
\hline $\begin{array}{l}\text { Tidak menerbitkan annual report berturut-turut per tanggal 31 } \\
\text { Desember }\end{array}$ & $(10)$ \\
\hline $\begin{array}{l}\text { Tidak memiliki data lengkap terkait dengan variabel penelitian } \\
\text { Tidak Mengungkapkan informasi mengenai CSR pada }\end{array}$ & $(30)$ \\
$\begin{array}{l}\text { annual report } \\
\text { Tidak menggunakan. mata uang Rupiah sebagai transaksi }\end{array}$ & $(8)$ \\
\hline$\quad$ Jumlah sampel perusahaan & $\mathbf{2 1}$ \\
\hline
\end{tabular}

Teknik Pengumpulan Data

Teknik pengumpulan data memakai data sekunder melalui teknik dokumentasi dan data sekunder. Yaitu data survey berupa annual report/laporan keuangan perusahaan (firm) manufacture di industri dasar dan kimia 5 tahun yaitu 2015-2019. Data itu didapat dari situs web BEI (www.idx.co.id) dan website resmi perusahaan.

\section{Definisi Operasionalisasi dan Pengukuran Variabel}

Terdapat tiga variabel independen yaitu GCG, kinerja keuangan, dan ukuran perusahaan. Variabel dependen dalam penelitian ini yaitu nilai perusahaan dan variabel moderasi yaitu CSR. Definisi operasional dan pengukuran variabel dapat dilihat pada Tabel 3.

Tabel 3. Definisi Operasional Variabel

\begin{tabular}{|c|c|c|c|}
\hline Variabel & Definisi & Pengukuran & Keterangan \\
\hline $\begin{array}{l}\text { Good Corporate } \\
\text { Governance } \\
\text { (Kepemilikan } \\
\text { Manajerial) }\end{array}$ & $\begin{array}{l}\text { persentase antara jumlah saham } \\
\text { yang dimiliki oleh manajemen } \\
\text { (dewan komisaris dan direktur) } \\
\text { dan total modal saham yang } \\
\text { dimiliki oleh manajemen (Vira \& } \\
\text { Wirakusuma, 2019). }\end{array}$ & $\begin{array}{l}K M \\
=(\text { Total saham yang dimiliki manajemen }) \\
\text { /(Total saham yang bererdar }) X 100 \%\end{array}$ & Rasio \\
\hline $\begin{array}{l}\text { Kinerja } \\
\text { Keuangan } \\
\text { (Return on } \\
\text { Assets) }\end{array}$ & $\begin{array}{l}\text { rasio margin profit yang biasa } \\
\text { dipakai perusahaan guna } \\
\text { mengukur kemampuannya dalam } \\
\text { memperoleh profit dari total asset } \\
\text { yang digunakan (Dewi \& Suputra, } \\
\text { 2019) }\end{array}$ & $R O A=\frac{\text { laba bersih } \text { after } \operatorname{tax}}{\text { total aset }} \times 100 \%$ & Rasio \\
\hline $\begin{array}{l}\text { Ukuran } \\
\text { Perusahaan }\end{array}$ & $\begin{array}{l}\text { skala besar kecilnya suatu asset } \\
\text { yang dimiliki oleh perusahaan } \\
\text { dalam aktivitas operasionalnya } \\
\text { (Wedayanti \& Wirajaya, 2018). }\end{array}$ & Firm Size = Ln (Total Asset $)$ & Rasio \\
\hline $\begin{array}{l}\text { Nilai } \\
\text { Perusahaan } \\
\text { (Tobins'Q) }\end{array}$ & $\begin{array}{l}\text { penilaian investor atas } \\
\text { keberhasilan perusahan yang } \\
\text { terlihat dari harga pasar bursa } \\
\text { efek (Meze \& Tohar, 2020). }\end{array}$ & Tobins $^{\prime} Q=\frac{\text { MVE }+ \text { DEBT }}{\text { TA }}$ & Rasio \\
\hline $\begin{array}{l}\text { Corporate } \\
\text { Social } \\
\text { Responsibility }\end{array}$ & $\begin{array}{l}\text { Pengungkapan informasi non } \\
\text { keuangan kepada pihak luar yang } \\
\text { berkepentingan (Hardian \& } \\
\text { Asyik, 2016). }\end{array}$ & $\operatorname{CSRDI} j=\frac{\mathrm{Xj}}{\mathrm{N}}$ & Rasio \\
\hline
\end{tabular}

\section{Teknik Analisis Data}

Teknik analisis dari penelitian ini menggunakan Warp PLS versi 7.0. Alasan penulis memilih alat teknik analisis ini karena memiliki kelebihan yaitu patokan sampel tidak harus besar dan data tidak harus diharuskan menggunakan multivariate normal distribution. 


\section{Evaluasi Model Pengukuran (Outer Model) \\ Uji Validitas \\ Validitas Konvergen (Convergent Validity)}

Uji validitas konvergen berkorelasi dengan esensial bahwa pengukur melalui konstruk harus memiliki hubungan yang tinggi. Uji ini dapat mengetahui nilai loading factor untuk tiap masing parameter konstruk. Aturan yang dipakai untuk mengevaluasi loading factor dapat dikatakan reliabel apabila memiliki keterkaitan > 7.0 dan untuk nilai AVE (Average Variance Extracted) harus sebesar > 0.5 (Ghozali \& Latan, 2015).

\section{Validitas Diskriminan (Discrimininant Validity)}

Uji validitas diskriminan bertujuan untuk menganalisis variable atau parameter dari kedua konstruk yang tidak seharusnya berkorelasi tinggi. Uji ini dipakai untuk memperkirakan validitas diskriminan mampu dinilai dengan melihat cross loading pada tiap masing variable harus $>0.70$. Metode lain dari uji ini dapat diketahui pada akar kuadrat AVE pada setiap masing konstruk dengan keterkaitan antara kosntruk lainnya dalam model.

\section{Uji Reliabilitas (Compose Reliability)}

Uji reliabilitas bertujuan untuk menunjukkan konsistensi, ketepatan, dan akurasi instrument untuk mengukur konstruk. Uji ini dapat dilakukan dengan dua cara: (1) Composite Reliability, merupakan data yang memiliki reliabilitas yang tinggi apabila > 0.7; (2) Cronbach Alpha, semua kosntruk diharapkan memiliki nilai > 7.0.

\section{Evaluasi Model Pengukuran (Inner Model) \\ R-Square}

Nilai Rsquare bertujuan untuk mengetahui seberapa signifikan pengaruh faktor laten eksogen pada variabel laten endogen apakah memiliki pengaruh yang substansive. Semakin tinggi nilai Rsquare, semakin baik pula model prediksi dan model penelitian yang diusulkan.

\section{Predictive Relevance $\left(\mathrm{Q}^{2}\right)$}

$\mathrm{Q}^{2}$ berfungsi untuk mempresentasikan sintesis dari cross validation dan fungsi fitting dengan prediksi dari observed variabel dan estimasi dari parameter konstruk. Suatu model dapat dikatakan memiliki predictive relevance apabila > 0 dan sebaliknya model tidak memiliki predictive relevance < 0 (Ghozali dan Latan, 2015).

\section{Uji Goodness of Fit Model}

Uji fit atau kelayakan model ini bertujuan untuk mengukur keakuratan fungsi regresi sampel dalam memperkirakan nilai sebenarnya. Indikator ini dapat dilihat melalui Average R-square (ARS), Average Path Coefficent (APC), dan Average Variance Inflation Factor (AVIF) dengan kriteria P-value untuk APC dan ARS $<0.05$ dan AVIF $<3.3$ namun $<5$ masih dapat diterima.

\section{Uji Hipotesis}

Untuk mengetahui pengujian hipotesis, maka dilakukan dengan melihat nilai probabilitas $(P$ value) dan TStatistic. Hipotesis data dianggap signifikan apabila nilai dari p value $<0.05$ dan dinyatakan tidak signifikan apabila $>0.05$

\section{HASIL DAN PEMBAHASAN \\ Analisis Outer Model \\ Convergent Validity}

Validitas konvergen (convergent validity) merupakan indikator refleksif dengan program Warp PLS versi 7.0 dilihat dari jilai loading factor dan dari nilai Average Variance Extracted ututk tiap konstruk yang diharapkan nilai akan >,70 dan 0,50.

Tabel 4. Uji Validitas Konvergen

\begin{tabular}{ccc}
\hline Variabel & $\begin{array}{c}\text { Loading } \\
\text { Factor }\end{array}$ & $\boldsymbol{A V E}$ \\
\hline KM & 1.000 & 1.000 \\
ROA & 1.000 & 1.000 \\
SIZE & 1.000 & 1.000 \\
TOBIN'S Q & 1.000 & 1.000 \\
\hline
\end{tabular}




\begin{tabular}{ccc}
\hline CSR & 1.000 & 1.000 \\
$\mathrm{KM}^{*} \mathrm{CSR}$ & 1.000 & 1.000 \\
ROA*CSR & 1.000 & 1.000 \\
SIZE*CSR & 1.000 & 1.000 \\
\hline \multicolumn{2}{l}{ Sumber: Data diolah Penulis, 2021 }
\end{tabular}

Tabel 4 menunjukkan hasil dari uji validitas konvergen untuk variabel-variabel penelitian ini. Pada pengujian ini diperoleh dari setiap variabel memiliki nilai loading factor $>0,70$ serta nilai AVE $>$ 0,50, sehingga ditarik simpulan bahwa semua variabel telah memenuhi kriteria rule of thumb (aturan) dari validitas konvergen.

\section{Discriminant Validity}

Validitas Diskriminan menyangkut prinsip bahwa insikator konstruk yang berbeda tidak boleh saling berkorelasi kuat satu sama lain. Validitas ini dapat dilihat dari cross loading atau dengan memperhitungkan nilai akar kuadrat $A V E$ dari tiap konstruk dengan hubungan antara konstruk lain dalam model.

Tabel 5. Uji Validitas Diskriminan

\begin{tabular}{ccc}
\hline Variabel & Cross Loading & Akar Kuadrat $\boldsymbol{A V E}$ \\
\hline KM & 1.000 & 1.000 \\
ROA & 1.000 & 1.000 \\
SIZE & 1.000 & 1.000 \\
TOBIN'S Q & 1.000 & 1.000 \\
CSR & 1.000 & 1.000 \\
KM*CSR & 1.000 & 1.000 \\
ROA*CSR & 1.000 & 1.000 \\
SIZE*CSR & 1.000 & 1.000 \\
\hline
\end{tabular}

Sumber: Data diolah Penulis, 2021

Tabel 5 menunjukkan hasil uji validitas diskriminan memperlihatkan nilai cross loading masing-masing variabel melebihi $(>0,7)$ dan nilai akar kuadrat AVE lebih besar dari korelasi antar variabel. Sehingga ditarik simpulan bahawa semua variabel memenuhi rule of thumb (aturan) dari validitas diskriminan.

\section{Reliabilitas (Composite Reliability)}

Uji reliabilitas dilakukan untuk menilai reliabilitas dari konstruk menggunakan indikator refleksif dengan melihat nilai Cronbach Aplha dan nilai Composite Reliability. Data menandakan reliabel atau konsisten jangka panjang jika $>0,7$.

Tabel 6. Uji Reliabilitas

\begin{tabular}{ccc}
\hline Variabel & Cronbach Alpha & Composite Reliability \\
\hline KM & 1.000 & 1.000 \\
ROA & 1.000 & 1.000 \\
SIZE & 1.000 & 1.000 \\
TOBIN'S Q & 1.000 & 1.000 \\
CSR & 1.000 & 1.000 \\
KM*CSR & 1.000 & 1.000 \\
ROA*CSR & 1.000 & 1.000 \\
SIZE*CSR & 1.000 & 1.000 \\
\hline Sumber: Data diolah Penulis, 2021
\end{tabular}

Tabel 6 menunjukkan hasil uji reliabilitas memperlihatkan nilai composite reliability untuk seluruh variabel pada penelitian >0,7. Artinya hasil keseluruhan outer model konstruk reflektif sudah memenuhi syarat atau reliabel. Sehingga apabila seluruh item instrumen penelitian kedua kalinya untuk menilai gejala yang sama akan mendapatkan hasil yang relatif konsisten. 


\section{Analisis Inner Model}

\section{R Square $\left(\mathbf{R}^{2}\right)$}

Perubahan nilai $\mathrm{R}^{2}$ berfungsi untuk menerangkan beberapa pengaruh faktor dari variabel laten eksogen pada variabel laten endogen (jika berpengaruh signifikan). Nilai R-kuadrat 0,$67 ; 0,33 ; 0,19$ menunjukkan model kuat, sedang, dan lemah.

Tabel 7. Nilai $\mathrm{R}^{2}$

\begin{tabular}{lc}
\hline & $\mathbf{R}^{2}$ \\
\hline Y (Nilai Perusahaan) & 0.504 \\
\hline Sumber: Data diolah Penulis, 2021
\end{tabular}

Tabel 7 menunjukkan nilai Rkuadrat menujukkan variabel nilai perusahaan (Y) didapatkan nilai sebesar 0,5. Artinya bahwa variabel $\mathrm{Y}$ dapat dijelaskan sebesar 50,4\% dengan variabel X1, X2, X3, dan Z. Sedang sisanya $49,6 \%$ dipengaruhi faktor oleh variabel lain yang tidak diamati dalam penelitian ini.

\section{Predictive Relevance $\left(\mathrm{Q}^{2}\right)$}

$\mathrm{Q}^{2}$ berfungsi untuk mempresentasikan sintesis dari cross validation dan fungsi fitting dengan perkiraan dari observed variabel dan dugaan dari parameter konstruk.

\begin{tabular}{lc}
\multicolumn{2}{c}{ Tabel 8. Nilai $\mathrm{Q}^{2}$} \\
\hline \multicolumn{2}{c}{$\mathbf{Q}^{2}$} \\
\hline Y (Nilai Perusahaan) & 0.503 \\
\hline Sumber: Data diolah Penulis, 2021
\end{tabular}

Tabel 8 menunjukkan nilai predictive relevance $\mathrm{Q}^{2}$ didapatkan nilai sebesar 0,503 , artinya model memiliki predictive relevance atau $\mathrm{Q}^{2}>0$.

\section{Uji Goodness of Fit Model}

Uji fit model bertujuan untuk menentukan sebuah model itu baik atau cocok (fit) atau tidak. Pada penelitian ini, uji fit model menggunakan tiga survey dan diantaranya: Path Coefficient (APC), Average R-Square (ARS), dan Average Variance Inflation Factor (AVIF).

Tabel 9. Nilai Uji Fit Model

\begin{tabular}{cccc}
\hline Indikator Fit Model & Indeks & P Value & Hasil \\
\hline APC & 0.169 & $\mathrm{P}=0.018$ & Diterima \\
ARS & 0.504 & $\mathrm{P}<0.001$ & Diterima \\
AVIF & 2.261 & & Diterima \\
AFVIF & 1.407 & & Diterima \\
\hline
\end{tabular}

Sumber: Data diolah Penulis, 2021

Berdasarkan hasil ujit fit model menunjukkan bahwa P-Value untuk APC dan ARS adalah < 0,05 serta AFVIF kurang dari 5, maka ditarik simpulan bahwa tidak ada multikolinearitas antar variabel. Dengan kata lain, model pada penelitian ini telah memenuhi syarat fit model.

\section{Uji Hipotesis}

Untuk menguji hipotesis dalam penelitian ini dengan bantuan software Warp PLS 7.0. Uji hipotesis ini bertujuan untuk membuktikan keabsahan suatu hipotesis atau dugaan selama proses penelitian. Korelasi antar konstruk diukur dengan mengetahui path coefficient. Jika P-value $<0,05$ maka hipotesis menujukkan signifikan, sebaliknya jika > 0,05 artinya tidak signifikan.

Tabel 10. Uji Hipotesis (Path Coefficient)

\begin{tabular}{llccc}
\hline & & $\boldsymbol{\beta}$ & P Values & Hasil \\
\hline $\mathrm{X} 1$ & $\rightarrow \mathrm{Y}$ & -0.11 & 0.123 & Tidak berpengaruh \\
$\mathrm{X} 2$ & $\rightarrow \mathrm{Y}$ & 0.165 & 0.04 & Berpengaruh positif signifikan \\
$\mathrm{X} 3$ & $\rightarrow \mathrm{Y}$ & -0.58 & $<0.001$ & Berpengaruh negatif signifikan \\
$\mathrm{X} 1 * \mathrm{CSR} \rightarrow \mathrm{Y}$ & 0.019 & 0.421 & Tidak dapat memoderasi \\
$\mathrm{X} 2 * \mathrm{CSR}$ & $\rightarrow \mathrm{Y}$ & -0.035 & 0.361 & Tidak dapat memoderasi \\
$\mathrm{X} 3 * \mathrm{CSR}$ & $\rightarrow \mathrm{Y}$ & -0.106 & 0.134 & Tidak dapat memoderasi \\
\hline
\end{tabular}

Sumber: Data diolah Penulis, 2021 
Tabel 10 dapat dijelaskan bahwa variabel X1 (GCG) diproksi oleh kepemilikan manajerial dengan tingkat signifikan sebesar 0,123>0,05, artinya KM membuktikan tidak berpengaruh pada nilai perusahaan. Variabel X2 (kinerja keuangan diproksi ROA) dengan tingkat signifikan sebesar 0,04 < 0,05 , artinya return on asset membuktikan pengaruh positif signifikan pada nilai perusahaan. Variabel X3 (ukuran perusahaan) dengan tingkat signifikan sebesar $<0,001<0,05$, artinya ukuran perusahaan/size membuktikan pengaruh negatif signifikan pada nilai perusahaan. Kemudian variabel Z (CSR) sebagai pemoderasi antara pengaruh variabel X1, X2, dan X3 pada Tobin's Q (nilai perusahaan) membuktikan bahwa CSR tidak dapat memoderasi pengaruh dari ketiga variabel bebas tersebut dengan tingkat signifikasi berturut-turut sebesar 0,$421 ; 0,361 ; 0,134$ yang $>0,05$.

\section{PEMBAHASAN}

\section{Hipotesis 1}

Hasil pengujian hipotesis pertama, diketahui bahwa GCG diproksi oleh kepemilikan manajerial tidak memengaruhi Tobin's Q (nilai perusahaan), karena perusahaan mungkin belum memperhatikan lebih kepemilikan manajerial. Perusahaan juga belum menerapkan kepemilikan manajerial terkelola secara wajr dan akurat untuk digunakan dalam penilaian kinerja dan untuk informasi tambahan dalam pengambil keputusan operasional perusahaan serta investor kurang memperhatikan pengaruh/dampak dari good corporate governance terhadap perusahaan dalam meningkatkan kekayaan principal. Hasil penelitian ini tidak cocok dengan teori keagenan, yang menjadi dasar teori untuk meminimumkan masalah antara manajemen dan principal. Sebab itu, perusahaan yang memiliki saham manajemen yang kecil cenderung menguntungkan pribadinya sendiri tanpa memperdulikan keinginan dari pihak pemagang saham sehingga justru menambah biaya bagi perusahaan dimana penambahan biaya ini akan menurunkan keuntungan bagi perusahaan dan berpengaruh pada penurunan saham. Penelitian ini sama dengan dilakukan oleh Isti'adah (2015) dan Onasis dan Robin (2016) yang menagatakan semakin banyak kepemilikan saham manajemen akan menurunkan nilai dari perusahaan, sehingga GCG (KM) membuktikan tidak ada pengaruh pada nilai perusahaan. Hasil berbeda ditunjukkan oleh Berliani \& Riduwan (2017) yang mengatakan bahwa kepemilikan manajerial membuktikan adanya pengaruh positif pada nilai perusahaan yang berarti bisa mengurangi konflik keagenan di dalam perusahaan.

\section{Hipotesis 2}

Hasil pengujian hipotesis kedua, diketahui bahwa kinerja keuangan diproksi return on asset menujukkan pengaruh positif signifikan pada Tobin's Q (nilai perusahaan), karena perusahaan sanggup mampu memanfaatkan total asset yang dimiliki perusahaan secara baik dan efisien yang diyakini memiliki peran penting dalam meningkatkan nilai suatu perusahaan. Hasil penelitian ini konsisten oleh yang dilakukan Dewi \& Suputra (2019) dan Purwantoro (2020)., membuktikan bahwa ROA memberikan pengaruh pada nilai perusahaan. Ini menandakan kinerja keuangan dapat membuat peningkatan nilai perusahaan melalui return on asset yang tinggi, sehingga dapat membuat kondisi perusahaan menguntungkan dengan membagikan sinyal positif kepada investor untuk membeli saham ke perusahaan. Hasil serupa ditunjukkan oleh Harningsih et al., (2019) dan Chumaidah \& Priyadi, (2018) yang menyatakan perusahaan dengan kinerja bagus dalam pengelolaan kekayaan aset dapat menghasilkan keuntungan tinggi dan memengaruhi nilai perusahaan.

\section{Hipotesis 3}

Hasil pengujian hipotesis ketiga, diketahui bahwa variabel ukuran perusahaan menujukkan pengaruh negatif signifikan pada Tobin's Q (nilai perusahaan), karena semakin skalanya besar perusahaan menandakan perusahaan tersebut tengah mengalami perkembangan kemajuan yang baik, dengan begitu menaikkan nilai sebuah perusahaan. Hal ini tentu mempermudah perusahaan untuk mendapatkan dana di pasar modal, karena investor lebih tertarik untuk berinvestasi di perusahaan besar sehingga lebih menguntungkan dan meningkatkan nilainya. Penelitian ini sejalan dengan penelitian Onasis dan Robin (2016), yang berpendapat bahwa seiring dengan pertumbuhan perusahaan dengan kenaikan sebesar satu di ukuran sebuah perusahaan, itu akan mengurangi nilainya di perusahaan. Dengan semakin besar suatu ukuran perusahaan maka dapat menimbulkan semakin sulitnya dewan direksi yang menyebabkan turunnya nilai perusahaan dan adanya faktor semakin tidak transparan manajemen perusahaan. Berbeda hasil ditunjukkan oleh Rudangga \& Sudiarta (2016) serta Rahma et al., (2014), berpendapat bahwa ukuran perusahaan memberikan pengaruh positif signifikan pada nilai perusahaan. 


\section{Hipotesis 4}

Hasil pengujian hipotesis keempat, diketahui bahwa CSR tidak mampu jadi pemoderasi pengaruh GCG (kepemilikan manajerial) terhadap Tobin's Q (nilai perusahaan). Hasil penelitian ini sama dengan Prastuti \& Budiarsih (2015) yang membuktikan bahwa CSR tidak mampu memoderasi pengaruh antara GCG dan Tobin's Q (nilai perusahaan). Namun, tidak mendukung penelitian dari Widianingsih (2018) yang menujukkan hasil bahwa CSR dapat memoderasi dari pengaruh kepemilikan manajerial (GCG) terhadap nilai perusahaan. GCG berkaitan dengan tanggung jawab oleh perusahaan pada pihak yang berkepentingan dari aktivitas ekonomi beserta dampaknya, sedangkan CSR merupakan bentuk perwujudan dari tindakan kepedulian dan tanggung jawab sosial untuk memperbaiki kerusakan lingkungan dan kesenjangan sosial yang diakibatkan aktivitas bisnis operasional perusahaannya. Dalam pelaksanaannya mengambil keputusan untuk kepentingan, perusahaan tentu harus memperhatikan tanggung jawab sosialnya. Jadi, bisa dikatakan nilai perusahaan tidak dapat ditingkatkan oleh kepemilikan manjerial pada perusahaan dengan mengungkapkan informasi non keuangannya (corporate social responsibility), atau sebaliknya nilai perusahaan tidak dapat diturunkan oleh kepemilikan manajerial dengan tidak mengungkapkan informasi CSR. Hal ini disebabkan karena perusahaan manufacture industry dasar dan kimia pada tahun 2015-2019 dengan total item CSR yang diungkapkan perusahaan besar masih memiliki jumlah saham yang dimiliki manajemen yang sedikit. Keadaan ini juga menandakan bahwa investor yang membeli saham perusahaan bukan hanya ditinjau dari corporate social responsibility suatu perusahaan, akan tetapi juga ditinjau dari faktor keuangan dan faktor lainnya.

\section{Hipotesis 5}

Hasil pengujian hipotesis kelima, diketahui bahwa CSR tidak mampu jadi pemoderasi pengaruh return on asset (kinerja keuangan) terhadap Tobin's Q. Hasil penelitian ini sama yang dilakukan oleh Harningsih et al., (2019); Wahyuni \& Hidayati (2018); dan Funawati \& Kurnia (2017), yang membuktikan CSR tidak dapat memoderasi pengaruh return on asset terhadap Tobin's Q dikarenakan dalam pengambilan keputusan untuk berinvestasi, investor lebih tertarik membeli saham yang menghasilkan keuntungan yang diharapkan tanpa memperdulikan adanya pengungkapan CSR. Hal ini tidak cocok dengan teori sinyal yang menerangkan bahwa profitabilitas yang tinggi menambah nilai perusahaan dan memberikan sinyal positif bagi investor untuk berinvestasi. Oleh karena itu, jika suatu perusahaan menguntungkan dan memiliki pengungkapan CSR tinggi, investor dapat terbujuk untuk menginvestasikan uangnya pada perusahaan dengan pengungkapan CSR yang baik sehingga menaikkan nilai perusahaan. Perbedaan dari teori ini diakibatkan oleh rendahnya nilai mutu kualitas pengungkapan CSR oleh perusahaan manufaktur di industri dasar dan kimia selam periode 2015-2019.

\section{Hipotesis 6}

Hasil pengujian hipotesis keenam, diketahui bahwa CSR tidak mampu jadi pemoderasi pengaruh ukuran perusahaan terhadap Tobin's Q. Penelitian ini serupa dengan yang dilakukan oleh Chumaidah \& Priyadi, (2018), berpendapat semakin besar kewajiban untuk memikul tanggung jawab sosialnya terhadap pemegang saham, maka tanggung jawab sosial perusahaan semakin besar. Hal ini memungkinkan investor tertarik untuk membeli saham untuk mendapatkan pengembalian keuntungan yang diharapkan terlepas dari pengungkapan CSR. Semakin besar ukuran dari perusahaan, semakin kompleks masalah yang melekat di perusahaan dengan banyaknya pengungkapan informasi CSR tidak dapat menjamin bahwa mampu meningkatkan kesejahteraan sosial masyarakat dan lingkungan sekitarnya secara efektif. Ini memungkinkan terjadinya masalah sosial dalam perusahaan yang membuat turunnya nilai perusahaan. Berbeda dengan penelitian oleh Pradita \& Suryono (2019) membuktikan bahwa CSR mampu menjadi pemoderasi pengaruh size/ukuran perusahaan pada nilai perusahaan dikarenakan CSR dinilai sangat penting jika ukuran dari perusahaan yang semakin tinggi akan menarik calon investor untuk membeli saham di perusahaan tersebut. Dengan begitu, pengungkapan CSR ini bisa meningkatkan nama baik dan popularitas perusahaan.

\section{KESIMPULAN}

Mengacu pada hasil pengujian di atas dengan bantuan software Warp PLS 17.0, yang menggunakan sampel 21 perusahaan manufaktur sub sektor industri dasar dan kimia yang terdaftar di BEI periode 2015 sampai 2019. Dari penelitian ini didapat kesimpulan sebagai berikut:

1. GCG (kepemilikan manajerial) tidak berpengaruh terhadap nilai perusahaan, ini dibuktikan melalui hasil path coefficient dengan nilai p-value 0,123 >0,05. Sedangkan kinerja keuangan 
(ROA) dan ukuran perusahaan berpengaruh positif dan negatif terhadap nilai perusahaan dengan nilai p-value 0,04 dan $<0,001$ yang lebih kecil dari 0,05 .

2. CSR sebagai variabel pemoderasi dalam penelitian ini, membuktikan hasil dari path coefficient tidak mampu memoderasi dari ketiga variabel bebas (independen) yaitu GCG, kinerja keuangan, dan ukuran perusahaan dengan nilai p-value berurutan 0,$421 ; 0,361 ; 0,134$ yang mana lebih besar (>) dari 0,05.

\section{SARAN}

1. Saran Praktis: Bagi perusahaan manufacture industri dasar dan kimia yang terdaftar di Bursa Efek Indonesia (BEI), diharapkan lebih memperhatikan faktor harga saham, seperti tingkat suku bunga, fluktuasi kurs rupiah, proyeksi kinerja perusahaan, dan aksi korporasi perusahaan yang memengaruhi kemampuan perusahaan untuk meningkatkan nilainya agar tidak mengalami kerugian besar di masa datang.

2. Saran Teoritis: Untuk peneliti selanjutnya, jika tertarik untuk melakukan kembali penelitian dengan topik sama, diharapkan dapat menambah variabel penelitian seperti stuktur modal, rasio likuiditas, solvabilitas, leverage, kebijakan deviden, manajemen laba, dan ukuran kepemilikan asing yang dapat dijadikan sebagai variabel bebas dan moderasi. Selain itu, adanya penambahan jumlah populasi dan sampel, periode tahun yang lebih panjang sehingga hasil penelitian dapat selalu diperbaruhi dan merespresentasikan pengaruh-pengaruh antar variabel yang lebih efektif terhadap nilai perusahan.

\section{REFERENSI}

Benne, K. K., \& Moningka, P. 2020. The Effect of Corporate Social Responsibility Information Disclosure on Firm Value With Profitability As an Moderating Variable in Mining Sector Companies Listed At Bei. Klabat Accounting Review, 1(1), 56-70.

Berliani, C., \& Riduwan, A. 2017. Pengaruh Good Corporate Governance, Kinerja Keuangan, Dan Ukuran Perusahaan Terhadap Nilai Perusahaan. Jurnal Ilmu Dan Riset Akuntansi, 6(3), 10371051.

Budianto, W., \& Payamta, P. 2014. Pengaruh Kepemilikan Manajerial Terhadap Nilai Perusahaan Dengan Kebijakan Dividen Sebagai Variabel Moderasi. Assets: Jurnal Akuntansi Dan Pendidikan, $3(1), 13$

Chumaidah, \& Priyadi, M. P. 2018. Pengaruh Profitabilitas dan Size Terhadap Nilai Perusahaan Dengan CSR Sebagai Variabel Pemoderasi. Jurnal Ilmu Dan Riset Akuntansi, 7(3), 1-20.

Dewi, N. M. L., \& Suputra, I. D. G. D. 2019. Pengaruh Profitabilitas Dan Leverage Pada Nilai Perusahaan Dengan Corporate Social Responsibility Sebagai Variabel Pemoderasi. E-Jurnal Akuntansi, 28(1), 26-54.

Funawati, R., \& Kurnia, K. 2017. Pengaruh Profitabilitas Terhadap Nilai Perusahaan Dengan Corporate Social Responsibility Sebagai Variabel Pemoderasi. Jurnal Ilmu Dan Riset Akuntansi, 6(11).

Ghozali, I., Hengky Latan. 2015. Konsep, Teknik, Aplikasi Menggunakan Smart PLS 3.0 Untuk Penelitian Empiris. BP Undip. Semarang

Hardian, A. P., \& Asyik, N. F. 2016. Kinerja Keuangan Dan Ukuran Perusahaan Terhadap Nilai Perusahaan, Csr Sebagai Variabel Moderasi. Jurnal Ilmu Dan Riset Akuntansi, 5(9), 1-16.

Harmono. 2011. Manajemen Keuangan. Jakarta: Bumi Aksara

Harningsih, S., Agustin, H., \& Setiawan, M. A. 2019. Pengaruh Kinerja Keuangan Terhadap Nilai Perusahaan Dengan Pengungkapan CSR Dan Kebijakan Dividen Sebagai Variabel Moderasi. Ranah Research Journal of Multidisciplinary Research and Development, 1(2), 199-209.

Haryono, U., \& Iskandar, R. 2015. Corporate Social Performance And Firm Value. International Journal Of Business And Management Invention, 4 (11), 69-75.

Isti'adah, U. 2015. Pengaruh Mekanisme Corporate Governance terhadap Nilai Perusahaan dengan Kulaitas Laba sebagai Variabel Intervening. Skripsi. Universitas Negeri Yogyakarta.

Kasmir, 2014. Analisis Laporan Keuangan, Edisi Pertama, Cetakan Ketujuh. Jakarta: Pt. Rajagrafindo Persada.

Lestari, F., \& Rahmayanti, D. 2019. Analisis Pengaruh Profitabilitas Terhadap Nilai Perusahaan Dengan Corporate Social Responsibility Sebagai Variabel Pemoderasi Pada Perusahaan Pertambangan Di Bei Tahun 2010-2014. Managament Insight: Jurnal Ilmiah Manajemen, 12(1), 24-40. 
Meze, M. F., \& Tohari, A. 2020. Faktor-Faktor Yang Mempengaruhi Nilai Perusahaan Dengan Ukuran Perusahaan Sebagai Variabel Pemoderasi Pada Perusahaan Pertambangan Yang Terdaftar Di Bursa Efek Indonesia Tahun 2016-2018. Seminar Nasional Manajemen, Ekonomi, Akuntansi (Vol. 5, No. 1, Pp. 330-338).

Onasis, K., \& Robin, R. 2016. Pengaruh Tata Kelola Perusahaan Terhadap Nilai Perusahaan Pada Perusahaan Sektor Keuangan Yang Terdaftar Di BEI. Bina Ekonomi, 20(1), 1-22.

Pradita, R. A., \& Suryono, B. 2019. Pengaruh Kinerja Keuangan Terhadap Nilai Perusahaan Dengan Pengungkapan Corporate Social Responsibility Sebagai Variabel Moderasi. Jurnal Ilmu Dan Riset Akuntansi, 8(2), 1-18

Prastuti, N. K. K., \& Budiarsih, N. I. G. A. 2015. Pengaruh Good Corporate Governance pada Nilai Perusahaan dengan Moderasi Corporate Social Responsibility. E-Jurnal Akuntansi Universitas Udayana, 13(1), 114-129.

Purwantoro, Y. 2020. Pengaruh Kinerja Keuangan Terhadap Nilai Perusahaan Dengan Good Corporate Governance Sebagai Variabel Moderasi Pada Perusahaan Pertambangan (Doctoral Dissertation, Stie Perbanas Surabaya).

Rahma, A., et al. 2014. Pengaruh Kepemilikan Manajerial, Kepemilikan Institusional, Dan Ukuran Perusahaan Terhadap Keputusan Pendanaan Dan Nilai Perusahaan (Studi Kasus Pada Perusahaan Manufaktur Yang Terdaftar Di Bursa Efek Indonesia Periode 2009-2012). Jurnal Bisnis Strategi, 23(2), 45-69.

Rudangga, I. G. N. G., \& Sudiarta, G. M. 2016. Pengaruh Ukuran Perusahaan, Leverage, Dan Profitabilitas Terhadap Nilai Perusahaan. E-Jurnal Manajemen, 5(7).

Sartono, A. 2010. Manajemen Keuangan Teori dan Aplikasi. Edisi 4. Yogjakarta: BPFE

Sayekti, Y. \& Wondabio, L. S. 2007. Pengaruh CSR Disclosure terhadap Earning Response Coefficient. Simposium Nasional Akuntansi X. Makassar.

Sugiyono. 2016. Metode Penelitian Kuantitatif, Kualitatif Dan R\&D, Cetakan Ke-24. Bandung: Cv Alfabeta.

Sujianto. 2001. Dasar-Dasar Management Keuangan. Yogyakarta:BPFE

Sujoko dan Subyantoro, Ugy. 2007. Pengaruh Struktur Kepemilikan Saham, Leverage, Faktor Intern Dan Faktor Ekstern Terhadap Nilai Perusahaan. Jurnal Manajemen Dan Kewirausahaan. Vol. 9 No.1. Maret 2007. Pp. 41-48.

Susilaningrum, C. 2016. The Effect of Return on Assets, Liquidity Ratio, and Solvency Ratio With the Disclosure of Corporate Social Responsibility (CSR) As the Moderating Variable. Jurnal Profitatabilitas, 8(1), 1-17.

Triagustina, L., Sukarmanto, E., \& Helliana, H. 2014. Pengaruh Return On Asset (ROA) Dan Return On Equity (ROE) Terhadap Nilai Perusahaan Pada Perusahaan Manufaktur Subsektor Makanan Dan Minuman Yang Terdaftar Di Bursa Efek Indonesia Periode 2010-2012. Prosiding Akuntansi, $28-34$.

Vira, A. N., \& Wirakusuma, M. G. 2019. Pengaruh Pengungkapan Corporate Social Responsibility Pada Nilai Perusahaan Dengan Good Corporate Governance Sebagai Pemoderasi. E-Jurnal Akuntansi Universitas Udaya, 26(2), 1299-1326.

Wahyuni, W., Ap, I. N. N., \& Hidayati, S. A. 2018. Pengaruh Profitabilitas Terhadap Nilai Perusahaan Dengan Pengungkapan Corporate Social Responsibility (CSR) Sebagai Variabel Pemoderasi (Studi Empiris Pada Perusahaan Pertambangan Yang Terdaftar Di Jakarta Islamic Index Periode 2010-2017). Jurnal Magister Manajemen Unram. 7(2), 72-85.

Wedayanti, L. P., \& Wirajaya, I. G. A. 2018. Pengaruh Pengungkapan Corporate Social Responsibility Pada Nilai Perusahaan Dengan Ukuran Perusahaan Sebagai Variabel Moderasi. E-Jurnal Akuntansi Universitas Udayana, 24(3), 2304-2332.

Widianingsih, D. 2018. Kepemilikan Manajerial, Kepemilikan Institusional, Komisaris Independen, serta Komite Audit pada Nilai Perusahaan dengan Pengungkapan CSR sebagai Variabel Moderating dan Firm Size sebagai Variabel Kontrol. Jurnal Akuntansi Dan Pajak, 19(1), 38-52. 